\title{
Clinical, ultrasonographical and histopathological aspects in Hashimoto's thyroiditis associated with malignant and benign thyroid nodules
}

\author{
Aspekty kliniczne, ultrasonograficzne i histopatologiczne choroby Hashimoto \\ związanej ze złośliwymi i łagodnymi guzkami tarczycy
}

Ioana Zosin, Melania Balaş

Department of Endocrinology, 'Victor Babeş' University of Medicine and Pharmacy Timişoara, Romania

\begin{abstract}
Intriduction: The reported prevalence of chronic autoimmune thyroiditis associated with differentiated thyroid cancer (DTC) is heterogeneous. The aim of this study was to evaluate some epidemiological, clinical, sonographical and histological features of operated thyroid nodules with background diffuse autoimmune thyroiditis.

Material and methods: The study included 411 cases with Hashimoto's thyroiditis (HT), of which 118 presented thyroid nodular disease (TND). Thyroidectomy was performed in 76 cases. Of these patients, 24 presented histologically confirmed DTC and 52 benign lesions. DTC types were as follows: papillary thyroid cancer (PTC) $(n=6)$, follicular variant of PTC (FVPTC) $(n=6)$, papillary microcarcinomas $(\mathrm{n}=8)$, follicular thyroid carcinoma $(\mathrm{n}=1)$ and the mixed form (classic PTC and FVPTC) $(\mathrm{n}=3)$. The benign nodules were dominated by: follicular adenoma $(48 \%)$, and colloid goitre $(40.3 \%)$.

Results: The sonographic features with predictive risk for malignancy in cases with HT associated with TND were represented by: solid composition, hypoechogenicity and microcalcifications. The characters of margins, the nodular shape and the type of vascularity do not seem to be as useful for identification of malignant nodules in HT. Fine needle-aspiration biopsy (FNAB) showed in DTC cases different cytological smears: malignant (ten), indeterminate (eight), benign (two), and non-diagnostic (four). In the group of benign nodules, the indeterminate smears represented also a significant percentage $(\mathrm{n}=12)$.

Conclusions: The incidence of TND associated with HT was $28.7 \%$. Among 76 operated cases, $31.5 \%$ presented DTC. The accuracy of FNAB in the preoperative diagnosis showed higher sensitivity $(90.0 \%)$ and specificity $(61.5 \%)$ compared to sonographic criteria. (Endokrynol Pol 2013; 64 (4): 255-262)
\end{abstract}

Key words: Hashimoto's thyroiditis, thyroid nodule, thyroid cancer

\section{Streszczenie}

Wstęp: Podawane w literaturze dane na temat rozpowszechnienia przewlekłego autoimmunologicznego zapalenia tarczycy związanego ze zróżnicowanym rakiem tarczycy (DTC, differentiated thyroid cancer) cechuje duża rozpiętość. Celem badania była ocena wybranych cech epidemiologicznych, klinicznych, ultrasonograficznych i histopatologicznych operowanych guzków tarczycy u pacjentów z rozlanym autoimmunologicznym zapaleniem tarczycy.

Materiał i metody: Do badania włączono 411 przypadków choroby Hashimoto (HT, Hashimoto thyroiditis), z czego 118 pacjentów zgłosiło się do lekarza z powodu choroby guzkowej tarczycy (TND, thyroid nodular disease). Tyroidektomię wykonano u 76 pacjentów, przy czym u 24 pacjentów badanie histopatologiczne wykazało DTC, a u pozostałych 52 - zmiany łagodne. Postacie DTC były następujące: rak brodawkowaty tarczycy (PTC, papillary thyroid cancer) $(\mathrm{n}=6)$, wariant pęcherzykowy PTC (FVPTC, follicular variant of papillary thyroid cancer) $(\mathrm{n}=6)$, mikroraki brodawkowate $(\mathrm{n}=8)$, rak pęcherzykowy tarczycy $(\mathrm{n}=1)$ i postać mieszana (klasyczny PTC i FVPTC) $(\mathrm{n}=3)$. Większość guzków łagodnych stanowiły gruczolaki pęcherzykowe (48\%) i wole koloidalne $(40,3 \%)$.

Wyniki: Cechy ultrasonograficzne związane z ryzykiem rozpoznania nowotworu złośliwego w przypadkach HT związanej z TND obejmowały: litą strukturę, hipoechogenność i mikrozwapnienia. Charakter brzegów, kształt guzkowaty i typ unaczynienia nie wydają się użytecznymi parametrami w identyfikacji guzków złośliwych w HT. Biopsja aspiracyjna cienkoigłowa (BAC) wykazała w przypadkach DTC różne obrazy cytologiczne: złośliwy (10), nieokreślony (8), łagodny (2) i niediagnostyczny (4). W grupie z guzkami łagodnymi nieokreślony obraz cytologiczny stanowił duży procent wyników $(\mathrm{n}=12)$.

Wnioski: Częstość występowania TND związanego z HT wyniosła 28,7\%. Wśród 76 operowanych pacjentów DTC stwierdzono w 31,5\% przypadków. Dokładność BAC w rozpoznaniu przedoperacyjnym cechowała się większą czułością $(90,0 \%)$ i swoistością $(61,5 \%)$ w porównaniu z kryteriami ultrasonograficznymi. (Endokrynol Pol 2013; 64 (4): 255-262)

Stowa kluczowe: choroba Hashimoto, guzek tarczycy, rak tarczycy

Prof. Ioana Zosin M.D., 'Victor Babeș' University of Medicine and Pharmacy Timișoara Department of Endocrinology Timisoara Emergency County Hospital no.1 Bd. Iosif Bulbuca no.10 300736, Timișoara, Romania, tel.: +40 356433 464, fax: +40 256486887 


\section{Introduction}

Dailey and Lindsay were the first to report in 1955 the association between Hashimoto's thyroiditis (HT) and differentiated thyroid cancer (DTC) [1]. Since then, many other studies have confirmed this coexistence with variable incidence rates. Several reports have established a prevalence of $11-36 \%$ of patients with coexistent HT and papillary thyroid carcinoma (PTC) [2-5]. The majority of these studies are based on retrospective analysis of surgical series. HT and DTC (mainly PTC) share some epidemiological features, like the relationship with dietary iodine and radiation exposure. Both diseases affect mainly women, showing also certain common molecular features. RET/PTC combinations are common in PTC, being associated with the characteristic nuclear changes [6]. Others have shown an increased PI3K/Akt expression in both diseases [7]. Unger et al. found expression of p63 in Hashimoto patients with PTC $[8,9]$.

Although the association between HT and DTC has been frequently reported, it is unknown whether these thyroid disorders share a common origin and whether the presence of HT affects the biologic behaviour of PTC.

The aim of this study was to present some epidemiological aspects regarding the prevalence of thyroid nodular disease (TND) in HT and to analyse the ultrasonographic (US) and cytological features of proven benign and malignant lesions, diagnosed in cases with background diffuse autoimmune thyroiditis.

\section{Material and methods}

The clinical material, represented by 411 cases of HT, issued from an iodine-replete area (the western plain of Romania), was evaluated retrospectively and prospectively (January 2008-April 2012).

A total of 293 patients presented the diffuse form of the disease and 118 associated TND.

Informed consent forms were obtained from all patients. The study was approved by the local Ethics Committee. The study was performed in accordance with the Helsinki Declaration and good clinical practice.

The inclusion criteria were: female and male subjects, all age groups and confirmed HT (by immunological investigations and thyroid US). In cases without detectable antibodies (Abs), the diagnosis was established by US and fine needle aspiration biopsy (FNAB).

Serum samples were tested for TSH (reference values: $0.46-4.67 \mathrm{mIU} / \mathrm{L}$ ) and free $\mathrm{T}_{4}$ (reference values: 0.71-1.85 ng/dL), using ARCHITECT i2000 SR (Abbot Diagnostics).
Antithyroid antibodies (AT Abs) were measured by CMIA, using Abbot AxSYM System. The normal values were for TPO Abs $<12 \mathrm{IU} / \mathrm{mL}$ and for Tg Abs $<35 \mathrm{IU} / \mathrm{mL}$.

Thyroid US was performed using a Picker sonograph equipped with a linear transducer of $7.5 \mathrm{MHz}$ and power Doppler capability. A nodule was defined as an intrathyroidal lesion of any size that was sonographically distinct from the surrounding thyroid parenchyma.

The US analysis of nodules comprised the following characteristics:

- the measurement of the largest nodular diameter (mm);

- the composition of nodule (solid, cystic);

- the nodular echogenicity (isoechoic, hypoechoic, hyperechoic);

- the halo sign (present, absent);

- the characters of nodular margins (well-defined, ill-defined);

- microcalcifications (absent, present);

- the nodular vascularity was quantified by Doppler US. Three types of nodule vascularity were described: type 1 - absence of flow signals; type 2 - increased perinodular vascularisation, and type 3 - increased perinodular and intranodular vascularisation.

FNAB was carried out in nodules $\geq 10 \mathrm{~mm}$ and in those presenting more than two suspicious US features. Aspirated findings were classified into one of four classical cytological categories: non-diagnostic, benign, indeterminate, and malignant.

Surgery was performed in 76 cases because of different reasons: family history of thyroid carcinoma (two cases), autonomous adenoma (two), cytological diagnosis (45), compressive symptoms and signs (19) and patients' desire (eight) (Fig. 1).

The performed surgery consisted of: total thyroidectomy \pm neck dissection, total lobectomy and isthmusec-

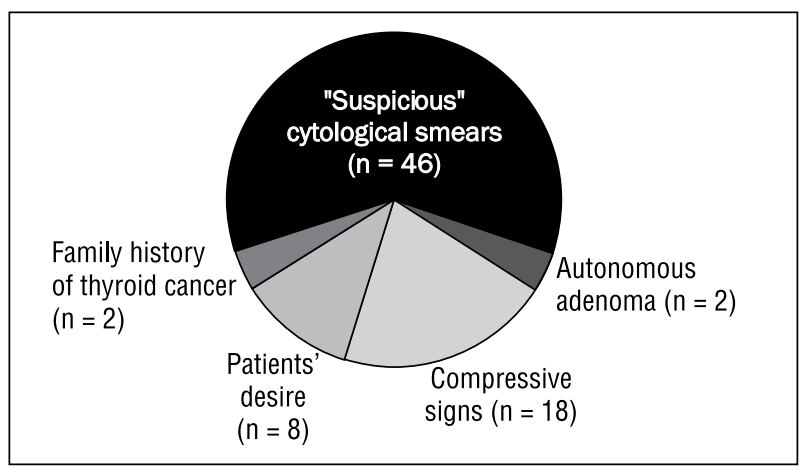

Figure 1. Indications for surgery (76 cases)

Rycina 1. Wskazania do zabiegu (76 przypadków) 
Table I. Epidemiological, functional and immunological data of HT cases with and without TND

Tabela I. Dane epidemiologiczne, czynnościowe i immunologiczne u pacjentów $z$ HT z towarzyszq̨cq TND $i$ bez towarzyszącej TND

\begin{tabular}{lccc}
\hline Parameter & $\begin{array}{c}\text { HT with TND } \\
(\mathbf{n}=\mathbf{1 1 8})\end{array}$ & $\begin{array}{c}\text { Diffuse HT } \\
(\mathbf{n}=\mathbf{2 9 3})\end{array}$ & $\mathbf{p}$ \\
\hline Mean age (yrs) \pm SD & $52.3 \pm 16.3$ & $47.65 \pm 15.32$ & $\mathrm{NS}^{\ddagger}$ \\
\hline Male (M)/Female (F) & $5 / 113$ & $21 / 272$ & $0.001^{\dagger}$ \\
\hline $\begin{array}{l}\text { TSH [mlU/L] } \\
\text { (mean } \pm \text { SD) }\end{array}$ & $13.30 \pm 7.47$ & $16.87 \pm 11.22$ & $\mathrm{NS}^{\dagger}$ \\
$\begin{array}{l}\text { fT4 [ng/dL] } \\
\text { (mean } \pm \text { SD) }\end{array}$ & $0.99 \pm 0.41$ & $1.06 \pm 0.34$ & $0.08^{\ddagger}$ \\
\hline $\begin{array}{l}\text { Positive anti TP0 Abs (significant } \\
\text { titers) }\end{array}$ & $99 / 118$ & $215 / 283$ & $0.37^{\ddagger}$ \\
\hline $\begin{array}{l}\text { Positive anti Tg Abs } \\
\text { (significant titers) }\end{array}$ & $60 / 118$ & $151 / 270$ & \\
\hline${ }^{+}$Student's unpaired $t$ test: fFisher's exact test & & &
\end{tabular}

Table II. Epidemiological, clinical and immunological data of operated cases with HT and TND

Tabela II. Dane epidemiologiczne, kliniczne i immunologiczne u operowanych pacjentów z HT i TND

\begin{tabular}{|c|c|c|c|}
\hline $\begin{array}{l}\text { Character } \\
\text { (no. of cases) }\end{array}$ & $\begin{array}{l}\text { Malignant nodules } \\
\quad(\mathrm{n}=24)\end{array}$ & $\begin{array}{l}\text { Benign nodules } \\
\quad(\mathrm{n}=52)\end{array}$ & $\mathbf{p}$ \\
\hline Age (mean \pm SD) (years) & $53.2 \pm 13.4$ & $49.8 \pm 13.1$ & $0.44^{\dagger}$ \\
\hline $\mathrm{M} / \mathrm{F}$ & $1 / 23$ & $4 / 48$ & $\mathrm{NS}^{\ddagger}$ \\
\hline Incidentaloma & 4 & 9 & $N S^{\ddagger}$ \\
\hline Compressive symptoms and signs & 4 & 18 & $0.17^{\ddagger}$ \\
\hline \multirow[t]{3}{*}{ Thyroid functionality } & Euthyroidism -21 & Euthyroidism - 44 & $\mathrm{NS}^{\ddagger}$ \\
\hline & Hypothyroidism -3 & Hyperthyroidism -2 & \\
\hline & & Hypothyroidism - 6 & \\
\hline Polinodular goitre & 0 & 2 & $\mathrm{NS}^{\ddagger}$ \\
\hline
\end{tabular}

'Student's unpaired $t$ test; 'Fisher's exact test

tomy or unilateral subtotal thyroidectomy, depending on the case. For malignant cases we used radioactive iodine remnant ablation (using 100-150 mCI ${ }^{131} \mathrm{I}$ ).

Non-operated patients were treated with thyroxine when hypothyroid and re-evaluated US two times per year.

\section{Statistical analysis}

Continuous data was expressed as means with standard deviations (SD). Categorical data was expressed as frequency and percentage. Baseline characteristics were compared using the Wilcoxon Rank Sum text and Fisher's exact test as appropriate.

The sensitivity, specificity, positive predictive value (PPV) and negative predictive value (NPV) of preoperative diagnosis using FNAB and US characteristics were calculated, with the final diagnosis established through morphopathological analysis of surgical specimens.

The statistical analyses were performed using SPSS version 14 for Windows (SPSS Inc, Chicago, IL, USA).

\section{Results}

The epidemiological, functional and immunological data of studied cases are depicted in Table I.

Some aspects of operated patients, classified after morphopathological diagnosis, are represented in Table II.

DTC cases were represented by: classical PTC $(n=6)$, follicular variant of PTC (FVPTC) $(n=6)$, papillary microcarcinoma (five cases - single carcinoma, two cases - multicentric carcinoma and one case - follicular variant), follicular thyroid carcinoma 
Table III. US characteristics of proven malignant and benign thyroid nodules with background diffuse HT

Tabela III. Charakterystyka ultrasonograficzna potwierdzonych złośliwych i łagodnych guzków tarczycy u pacjentów z rozlanq HT

\begin{tabular}{|c|c|c|c|}
\hline $\begin{array}{l}\text { Character } \\
\text { (no. of cases) }\end{array}$ & $\begin{array}{l}\text { Malignant nodules } \\
\qquad(\mathrm{n}=24)\end{array}$ & $\begin{array}{l}\text { Benign nodules } \\
\quad(n=52)\end{array}$ & $\mathbf{p}$ \\
\hline Largest nodular diameter (mean \pm SD) [mm] & $24 \pm 10$ & $28 \pm 14$ & $0.21^{\dagger}$ \\
\hline \multicolumn{4}{|l|}{ Composition } \\
\hline Predominantly solid & 22 & 31 & $0.006^{\ddagger}$ \\
\hline Predominantly cystic & 2 & 21 & \\
\hline \multicolumn{4}{|l|}{ Echogenicity } \\
\hline Isoechoic & 5 & 21 & $0.001^{\#}$ \\
\hline Hypoechoic & 19 & 18 & \\
\hline Hyperechoic & 0 & 13 & \\
\hline \multicolumn{4}{|l|}{ Halo } \\
\hline Absent or thick, irregular & 19 & 22 & $0.07^{\ddagger}$ \\
\hline Thin, regular & 5 & 30 & \\
\hline Margins & & & $0.08^{\ddagger}$ \\
\hline Well-defined & 11 & 35 & \\
\hline Ill-defined & 13 & 17 & \\
\hline Microcalcifications & & & $<0.0001^{\ddagger}$ \\
\hline Absent & 9 & 44 & \\
\hline Present & 15 & 8 & \\
\hline Height/width $\geq 1$ & 8 & 11 & $0.26^{\ddagger}$ \\
\hline \multicolumn{4}{|l|}{ Vascularity pattern } \\
\hline 1 & 8 & 16 & $0.83^{\#}$ \\
\hline 2 & 8 & 21 & \\
\hline 3 & 8 & 15 & \\
\hline
\end{tabular}

( $\mathrm{n}=1)$, and mixed form (classic PTC associated with FVPTC) $(\mathrm{n}=3)$.

Preoperative FNAB of DTC cases revealed the following cytological diagnosis: malignant in ten cases, benign in two cases, indeterminate in eight patients, and non-diagnostic in four patients.

Histopathological diagnosis of benign lesions was represented by: follicular adenoma $(\mathrm{n}=25)$, colloid goitre $(n=21)$, Hürthle cell adenoma $(n=2)$, follicular hyperplasia $(\mathrm{n}=2)$, and nodular HT $(\mathrm{n}=2)$. The cytological diagnosis of these cases was as follows: malignant in three patients, benign in 24 subjects, indeterminate in 12 patients, and non-diagnostic in two cases.

The US characteristics of proven benign and malignant nodules with background HT are depicted in Table III.

The diagnostic accuracy of US characteristics for malignant nodules is depicted in Table IV and the risk factors for malignancy are presented in Table $\mathrm{V}$.
The US parameters (solid composition, hypoechoic appearance, halo, microcalcifications, margins, vascularity) of large malignant thyroid nodules (> $15 \mathrm{~mm}$ diameter) did not differ significantly from the smaller ones ( $<14 \mathrm{~mm}$ diameter).

In 39 cases, the US features of benignity were corroborated with cytological and morphopathological diagnoses (Table VI). Table VII shows the cytological and the morphopathological diagnoses of operated cases. The sensitivity, specificity, PPV and NPV of FNAB are shown in Table VIII.

\section{Discussion}

The association between TND and autoimmune thyroiditis is nowadays well-recognised.

In the present analysis, the prevalence of this coexistence was $28.7 \%$. Among 76 operated cases with HT and TND, there were diagnosed $68.4 \%$ benign nodules and $31.5 \%$ DTC. Others have found a lower prevalence of 
Table IV. Diagnostic accuracy of US features in malignant nodules with background HT Tabela IV. Dokładność diagnostyczna cech ultrasonograficznych guzków złośliwych u pacjentów z HT

\begin{tabular}{lccccc}
\hline Parameter & Sensitivity (\%) & Specificity (\%) & $\begin{array}{c}\text { Positive predictive } \\
\text { value (\%) }\end{array}$ & $\begin{array}{c}\text { Negative predictive } \\
\text { value (\%) }\end{array}$ & Accuracy (\%) \\
\hline Solid composition & $22 / 24(91.7)$ & $21 / 52(40.4)$ & $22 / 53(41.5)$ & $21 / 23(91.3)$ & $43 / 76(56.6)$ \\
\hline Hypoechoic appearance & $19 / 24(79.2)$ & $34 / 52(65.4)$ & $19 / 37(51.4)$ & $34 / 39(87.2)$ & $53 / 76(69.8)$ \\
\hline Microcalcifications & $15 / 24(62.5)$ & $44 / 52(84.7)$ & $15 / 23(65.3)$ & $44 / 53(83.1)$ & $59 / 76(77.7)$ \\
\hline Absent or thick, irregular halo & $19 / 24(79.2)$ & $24 / 52(46.2)$ & $19 / 47(40.5)$ & $24 / 29(82.8)$ & $43 / 76(56.6)$ \\
\hline Poorly defined margins & $17 / 24(70.9)$ & $40 / 52(77)$ & $17 / 29(58.7)$ & $40 / 47(85.1)$ & $57 / 76(75)$ \\
\hline Intranodular vascularity & $8 / 24(33.4)$ & $37 / 52(71.2)$ & $8 / 23(34.8)$ & $37 / 53(70)$ & $45 / 76(59.3)$ \\
\hline
\end{tabular}

Table V. Risk factors for malignancy of thyroid nodules in $\mathrm{HT}$

Tabela V. Czynniki ryzyka złośliwego charakteru guzków tarczycy u pacjentów $z$ HT

\begin{tabular}{ll}
\hline Risk factor & $\begin{array}{c}\text { Relative risk } \\
(\mathbf{9 5} \% \mathbf{C I})\end{array}$ \\
\hline Predominantly solid composition & $1.5(1.1-1.9)$ \\
\hline Hypoechoic & $2.2(1.4-3.5)$ \\
\hline Absent halo & $1.2(0.7-2.0)$ \\
\hline III defined margins & $1.6(0.9-2.8)$ \\
\hline Microcalcifications & $4.0(1.9-8.2)$ \\
\hline Height/width $\geq 1$ & $1.5(0.7-3.4)$ \\
\hline Size $>15$ mm & $0.7(0.4-1.0)$ \\
\hline Intranodular vascularity & $1.1(0.5-2.3)$ \\
\hline
\end{tabular}

HT and benign TND vs. HT and DTC (6.7\% vs. $23.8 \%)$ [10-12].

Some investigators have shown that the incidence rate of HT is 2.77 times higher in cases with PTC than in those with benign thyroid disease. At the same time, in patients with DTC, the incidence rate of the association with HT is 1.99 times higher in those with PTC than in cases with other forms of thyroid carcinoma [2, 3]. HT seems to be a stronger predictor for PTC than other risk factors [13].

The reported prevalence of microcarcinomas in HT is $36.6 \%$ [12]. The association of HT with primary thyroid lymphoma has been noted [15, 16].

The heterogeneity of the coexistence of DTC and HT in different studies seems to be related to different factors (individual differences in patient selection, indications for thyroidectomy, the level of pathological examination) [17-19].

In the present study, between diffuse HT and HT associated with TND, significant differences were observed regarding mean age (higher in nodular cases) and TSH levels (more increased in the diffuse form) (Table I).
The clinical parameters did not significantly differ in proven benign and malignant nodules (Table II). Some investigators observed the same aspects [20]. The morphopathological analysis showed in the DTC group different variants of PTC (classical form: six cases, follicular variant of PTC-FVPTC: six, papillary microcarcinomas: eight, follicular thyroid carcinoma-FTC: one patient and the mixed form-PTC and FVPTC: three cases).

The literature also describes other types of malignant lesions such as medullary carcinomas and even anaplastic thyroid cancer [21]. Generally, the percentages of PTC exceed those of FTC and medullary carcinoma [20-22].

The cases with benign nodules presented the following diagnoses: follicular adenomas, colloid goitres, Hürthle cell adenomas, follicular hyperplasia, and nodular or focal Hashimoto's thyroiditis, similar to other reported studies [20].

Analysing the US characteristics of proven malignant nodules $v s$. benign ones in HT, we remarked significant differences regarding the following features: composition $(\mathrm{p}=0.006)$, echogenicity $(\mathrm{p}=0.001)$, and the presence of microcalcifications $(\mathrm{p}<0.0001)$. While most malignant nodules were solid, hypoechoic, with microcalcifications, the benign ones presented welldefined margins (Table III).

The classical US characteristics of malignancy in a thyroid nodule are represented by: marked hypoechoic aspect, solid composition, absent halo, ill-defined margins, microcalcifications, predominantly central vascularity, and a certain shape (more tall than wide) [24-28].

The US characters of benignity are considered the following: the presence of a cystic component, a sponge-like structure, hyperechogenicity, present halo (thin, regular), well-defined margins, and no central vascularity $[29,30]$.

Since 1990, several studies have analysed the relation between specific US characteristics of thyroid nodules and malignancy [30, 31]. Most studies have remarked a limitation of specificity and sensitivity of 
Table VI. Corroboration of US features, cytological and morphopathological pictures in 39 benign nodules with HT Tabela VI. Potwierdzenie cech ultrasonograficznych, obrazu cytologicznego i obrazu histopatologicznego w 39 tagodnych guzkach u pacjentów z HT

\begin{tabular}{llll}
\hline US pattern & No of cases & Cytological diagnosis & Morphopathological diagnosis \\
\hline Sponge-like & 6 & Benign -2 & Colloid goitre -2 \\
& & Indeterminate -4 & Follicular adenoma -4 \\
\hline Cyst with colloid clot & 20 & Benign -8 & Colloid goitre -8 \\
& & Indeterminate -10 & Follicular adenoma -9 , Hürthle cell adenoma -1 \\
& Malignant -2 & HT -2 \\
\hline 'White knight' & 13 & Benign -6 & Colloid goitre -6 \\
& & Indeterminate -5 & Follicular adenoma -7 \\
& Non-diagnostic -2 & \\
\hline
\end{tabular}

Table VII. Correlation of cytological and histopathological diagnoses in malignant and benign nodules with HT background Tabela VII. Korelacja między rozpoznaniem cytologicznym i rozpoznaniem histopatologicznym w przypadku guzków złośliwych i łagodnych u pacjentów z HT

\begin{tabular}{|c|c|c|c|c|c|c|c|c|c|c|}
\hline \multirow[b]{2}{*}{ Cytology } & \multicolumn{9}{|c|}{ Morphopathology } & \multirow[b]{2}{*}{ F Hype } \\
\hline & CG & HT & FA & HCA & PTC & FVPTC & FTC & Mixed PTC & PmC & \\
\hline $\begin{array}{l}\text { Benign } \\
(n=26)\end{array}$ & 20 & & 2 & & & & & & 2 & 2 \\
\hline $\begin{array}{l}\text { Indeterminate } \\
(\mathrm{n}=20)\end{array}$ & & & 11 & 1 & & 5 & 1 & & 2 & \\
\hline $\begin{array}{l}\text { Malignant } \\
(\mathrm{n}=13)\end{array}$ & & 2 & & 1 & 6 & & & 3 & 1 & \\
\hline $\begin{array}{l}\text { Non-diagnostic } \\
(\mathrm{n}=6)\end{array}$ & & & 2 & & & 1 & & & 3 & \\
\hline
\end{tabular}

Table VIII. Accuracy of FNAB in the preoperative diagnosis of thyroid nodules in patients with background HT (65 cases) Tabela VIII. Dokładność BAC w rozpoznaniu przedoperacyjnym guzków tarczycy u pacjentów z HT (65 przypadków)

\begin{tabular}{|c|c|c|}
\hline \multirow[b]{2}{*}{$\begin{array}{l}\text { Preoperative FNAB } \\
\text { diagnosis }\end{array}$} & \multicolumn{2}{|c|}{ Postoperative histopathological diagnosis } \\
\hline & $\begin{array}{l}\text { Malignant nodules } \\
\quad(n=20)\end{array}$ & $\begin{array}{l}\text { Benign nodules } \\
\quad(n=41)\end{array}$ \\
\hline Malignant (13) & 10 & 3 \\
\hline Benign (26) & 2 & 24 \\
\hline Non-diagnostic (6) & 4 & 2 \\
\hline Indeterminate (20) & 8 & 12 \\
\hline
\end{tabular}

Sensitivity 90.0\%; Specificity 61.5\%; PPV 54.5\%; NPV 92.3\%; Accuracy 64.6\%.

specific US features in the prediction of malignancy. It is considered that no individual US feature has high sensitivity and a good specificity for the detection of malignancy.
It is difficult to establish if the US characteristics of malignancy are the same in the general population and in cases with background HT. Given the hypoechogenicity, specific echostructure and increased vascularity of HT, it seems reasonable to question whether existing guidelines are appropriate for this particular patient population [32]. No individual US parameter is suitable for preoperative diagnosis of malignancy in HT. Ultrasonographically, HT and HT associated with PTC may present very similar pictures $[20,33,34]$. The accuracy of US analysis of thyroid cancer in the general population does not seem totally different from that performed in cases with DTC with background HT (see Table VIII).

Anderson et al. observed that in malignant nodules within diffuse HT, all types of calcifications were more prevalent (microcalcifications, macrocalcifications and peripheral eggshell calcifications). At the same time, they decided that margin characteristics and vascular- 
ity did not seem to be as useful in patients with HT background [32].

Liu ascertained that the presence of poorly defined margins was the only US significant parameter for the differentiation of benign nodules vs. malignant in HT [20].

The analysis of US features of malignant nodules in HT with respect to size did not reveal significantly different aspects between large nodules $(\geq 15 \mathrm{~mm})$ and small nodules $(<14 \mathrm{~mm}$ ). This aspect, observed also by others $[35,36]$, enlarges the opportunity for cytological examinations for small thyroid nodules.

Some investigators [37,38] have preferred to consider a more pattern-oriented US approach as an alternative to the analysis of individual features. More nodular patterns with or without indication for FNAB were depicted. They consider biopsy mandatory in the following four patterns: hypoechoic nodule with microcalcifications; hypoechoic nodule with coarse calcifications; well-marginated, solid, ovoid nodules with a thin hypoechoic halo; and solid mass with refractive shadowing from the edges.

The same authors found that the use of a pattern approach to thyroid nodules is highly sensitive and specific for benignity. Four patterns invariably benign were identified (histological diagnosis). The patterns with no indication for FNAB are represented by the following: 1 - spongiform nodule ('puff pastry'); 2 - cyst with colloid clot; 3 - ' giraffe', and 4- hyperechoic nodule ('white knight') [37, 38].

We detected 39 cases with a 'benign' US pattern (spongiform: six cases; cyst with colloid clot: 20 , and 'white knight': 13 cases). FNAB results were dominated by indeterminate and benign smears $(19,16$ patients respectively). The histological analysis detected always benign nodules.

FNAB showed in DTC cases different cytological smears: malignant (ten), indeterminate (eight), benign (two), and non-diagnostic (four). In the group of patients with benign nodules, the indeterminate smears represented also a significant percentage (29.2\%) (Table VII). Some investigators report that $25-50 \%$ of cytological indeterminate nodules prove to be malignant upon final morphopathological diagnosis [37]. The American Thyroid Association and the European Thyroid Association recommend partial or near-total thyroidectomy for patients with indeterminate nodular cytology [27, 40].

Recently, investigators have studied the potential of clinical, radiological, and molecular markers to predict cancer or benignity. The use of multivariate assessment demonstrated the benefits of an approach using several risk factors in conjunction with cytological findings.

The clinical variables considered able to predict malignancy are: age ( $<18-25 \mathrm{yr})$, patient sex (male) and nodule size $[28,30,41]$. Others suggest no influence of nodule size on cancer risk.

The corroboration of cytological and morphopathological diagnoses in our cases (presented in Table VII) showed a low percentage of false-negative $(n=2)$ and false-positive cases $(n=3)$.

The accuracy of FNAB in the preoperative diagnosis of thyroid nodules in cases with background HT (presented in Table VIII) showed a sensitivity of $90.0 \%$ and a specificity of $61.5 \%$, higher values than those of US criteria.

The significant occurrence of follicular lesions resulted in an important percentage of indeterminate cytological smears. This aspect has also been observed in other studies [20,42, 43].

Indeterminate smears may induce cytologic diagnostic errors in HT, as a result of overlapping cytologic features, particularly among: Hürthle cell neoplasm, follicular neoplasm, PTC, and others.

\section{Conclusions}

The diagnosis of TND with background diffuse HT imposes systematically thyroid US.

In the present study, the prevalence of TND associated with HT was $28.7 \%$. Among the operated cases (76 patients), $31.5 \%$ presented different forms of DTC and $68.4 \%$ various benign lesions.

The US characteristics of benign and malignant nodules within diffuse HT seem to be generally similar to those described in the general population. The US features with predictive risk for malignancy in cases with HT associated with TND were represented by: solid composition, hypoechogenicity and microcalcifications. The characters of margins, the nodular shape and the type of vascularity do not seem to be as useful for identification of malignant nodules in HT.

While DTC cases were dominated by microcarcinomas, classical PTC and PTCFV, the benign nodules were mainly represented by follicular lesions (follicular adenoma, Hürthle cell adenoma and follicular hyperplasia). The important prevalence of follicular lesions with indeterminate smears explains the significant number of operated cases.

The accuracy of preoperative FNAB (sensitivity $90.0 \%$, specificity $61.5 \%$, NPV $92.3 \%$ ) was superior to that of US criteria. 


\section{References}

1. Dailey ME, Lindsay S,Skahen R. Relation of thyroid neoplasms to Hashimoto disease of the thyroid gland. AMA Arch Surg 1955; 70: 291-297.

2. Singh B, Shaha AR, Trivedi H. Coexistent Hashimoto's thyroiditis with papillary thyroid carcinoma: impact on presentation, management and outcome. Surgery 1999; 126: 1070-1077.

3. Cipolla C, Sandonato L, Gracefa G et al. Hashimoto thyroiditis coexistent with papillary thyroid carcinoma. Am Surg 2005; 71: 874-878.

4. Mazopakis EE, Anastasios AT, Dalieraki-Ott EI et al. Coexistence of Hashimoto's thyroiditis with papillary thyroid carcinoma. A retrospective study. Hormones 2010; 9: 312-317.

5. Fiore E, Rago T, Latrofa F et al. Hashimoto's thyroiditis is associated with papillary thyroid carcinoma: role of TSH and of treatment with L-thyroxin. Endocr Relat Cancer 2011; 18: 429-437.

6. Nikiforova MN, Caudill CM, Biddinger P W et al. Prevalence of RET/ PTC rearrangements in Hashimoto's thyroiditis and papillary thyroid carcinomas. Int J Surg Pathol 2002; 10: 15-22.

7. Larson SD, Jackson LN, Riall TS et al. Increased incidence of welldifferentiated thyroid cancer associated with Hashimoto's thyroiditis and the role of the PI3K/Akt pathway. J Am Coll Surg 2007; 204: 764-773.

8. Unger P, Ewart M, Wang BY et al. Expression of p63 in papillary thyroid carcinoma and in Hashimoto's thyroiditis: a pathobiologic link? Hum Pathol 2003; 34: 764-769.

9. Burnstein DE, Nagi C, Wang BY et al. Immunohistochemical detection of p53 homolog p63 in solid cell nests, papillary thyroid carcinoma and Hashimoto's thyroiditis: A stem cell hypothesis of papillary carcinoma oncogenesis. Hum Pathol 2004; 35: 465-473.

10. Pisanu A, Piu S, Cois A et al. Coexisting Hashimoto's thyroiditis with differentiated thyroid cancer and benign thyroid diseases: indications for thyroidectomy. Chir Ital 2003; 55: 365-372.

11. Imani EF, Aminorroaya A, Soheilipour F et al. Sonographic and functional characteristics of thyroid nodules in a population of adult people in Isfahan. Endokrynol Pol 2010; 61: 188-191.

12. Karaszewski B, Wilkowski M, Tomasiuk T et al. The prevalence of incidentaloma-asymptomatic thyroid nodules in the Tricity (Gdansk, Sopot, Gdynia) population. Endokrynol Pol 2006; 57: 196-200.

13. Kim KW, Park YJ, Kim EH et al. Elevated risk of papillary thyroid cancer in Korean patients with Hashimoto's thyroiditis. Head Neck 2011; 33: 691-695.

14. Kim DL, Song KH, Kim SK. High prevalence of carcinoma in ultrasonography-guided fine needle aspiration cytology of thyroid nodules. Endocr J 2008; 55: 135-142.

15. Miller BS, Gauger PG. Thyroid lymphoma arising from Hashimoto's thyroiditis. J Clin Endocrinol Metab 2006; 91: 3711-3712.

16. Moshynska OV, Saxena A. Clonal relationship between Hashimoto thyroiditis and thyroid lymphoma. J Clin Pathol 2008; 61: 438-444.

17. Tamimi D M. The association between chronic lymphocytic thyroiditis and thyroid tumors. Int J Surg Pathol 2002; 10: 141-146.

18. Kim EY, Kim WG, Kim WB et al. Coexistnce of chronic lymphocytic thyroiditis is associated with lower recurrence rates in patients with papillary thyroid carcinomas. Clin Endocrinol (Oxf) 2009; 71: 581-586.

19. Feldt-Rasmussen U, Rasmussen AK. Autoimmunity in differentiated thyroid cancer: significance and related clinical problems. Hormones 2010; 9: 109-117.

20. Liu FH, Hsueh C, Chang NY et al. Sonography and fine-needle aspiration biopsy in the diagnosis of benign versus malignant nodules in patients with autoimmune thyroiditis. J Clin Ultrasound 2009; 37: 487-492.

21. Ahn D, Heo SJ, Park JH et al. Clinical relationship between Hashimoto's thyroiditis and papillary thyroid cancer. Acta Oncologica 2011; 50: $1228-1234$.
22. Ohmori N, Miyakawa M, Ohmori K et al. Ultrasonographic findings of papillary thyroid carcinoma with Hashimoto thyroiditis. Intern Med 2007; 46: 547v550.

23. Trimboli P, Ulisse S, Graziano FM et al. Trend in thyroid carcinomas size, age at diagnosis and histology in a retrospective study of 500 cases diagnosed over 20 years. Thyroid 2006; 16: 1151-1155.

24. Moon WJ, Jung SL, Hyun J et al Benign and malignant thyroid nodules: US differentiation multicenter retrospective study. Radiology 2008; 247: 762-770

25. Mukasa K, Noh JY, Kunii Y et al. Prevalence of malignant tumors and adenomatous lesions detected by ultrasonographic screening in patients with autoimmune thyroid diseases. Thyroid 2011; 21: 37-41.

26. Frates MC, Benson CB, Charboneau JW et al. Management of thyroid nodules detected at US: Society of radiologists in ultrasound consensus conference statement. Radiology 2005; 237: 794-800.

27. Cooper DS, Doherty GM, Haugen BR et al. Management guidelines for patients with thyroid nodules and differentiated thyroid cancer Thyroid 2006; 16: 109-142.

28. Lin JD, Chao TC, Huang BY et al. Thyroid cancer in the thyroid nodules evaluated by ultrasonography and fine-needle aspiration cytology. Thyroid 2005; 15: 708-717.

29. Virmani V, Hammond I. Sonographic patterns of benign thyroid nodules: verification in our institution. AJR 2011; 196: 891-895.

30. Frates $\mathrm{MC}$, Benson $\mathrm{CB}$, Doubilet PM et al. Prevalence and distribution of carcinomas in patients with solitary and multiple thyroid nodules on sonography. J Clin Endocrinol Metab. 2006; 91: 3411-3417.

31. Kim EK, Park CS, Chung NY et al. New sonographic criteria for recommending fine-needle aspiration biopsy of nonpalpable solid nodules of the thyroid. AJR 2002; 178: 687-691.

32. Anderson L, Middleton WD, Teefey SA et al. Hashimoto thyroiditis: part 2. Sonographic analysis of benign and malignant nodules in patients with diffuse Hashimoto thyroiditis. AJR 2010; 195: 216-222.

33. Cunha LL, Ferreira LC, Marcello MA et al. Clinical and pathological implications of concurrent autoimmune thyroid disorders and papillary thyroid cancer. J Thyroid Res 2011; doi:10.4061/2011/387062.

34. Isik S, Gokay F, Ozuguz U et al. Comparison of the prevalence and sonographic features of thyroid nodules accompanying autoimmune thyroid diseases. Pol J Endocrinol 2010; 6: 658-664.

35. Popowicz B, Klencki M, Lewinski A et al. The usefulness of sonographic features in selection of thyroid nodules for biopsy in relation to the nodule's size. Eur J Endocrinol 2009; 161: 103-111.

36. Slowinska-Klencka D, Popowicz B, Lewinski A et al. The fine-needle aspiration biopsy efficacy of small thyroid nodules in the area of recently normalized iodine supply. Eur J Endocrinol 2008; 159: 747-754.

37. Reading CC, Charboneau JW, Hay ID et al. Sonography of thyroid nodules: a "classic pattern" diagnostic approach. Ultrasound Q 2005; 21: 157-165.

38. Bonavita JA, Mayo J, Babb J et al. Pattern recognition of benign nodules at ultrasound of the thyroid: which nodules can be left alone? AJR; 193: 207-213.

39. Alexander EK. Approach to the patient with a cytologically indeterminate thyroid nodule. J Clin Endocrinol Metab 2008; 93: 4175-4182.

40. Pacini F, Schlumberger M, Dralle $\mathrm{H}$ et al. European consensus for the management of patients with differentiated thyroid carcinoma of the follicular epithelium. Eur J Endocrinol 2006; 154: 787-803.

41. Boelaert K, Horacek J, Holder RL et al. Serum thyrotropin concentration as a novel predictor of malignancy in thyroid nodules investigated by fine-needle aspiration. J Clin Endocrinol Metab 2006; 91: 4295-4301.

42. Lorini R, Gastaldi R, Traggiai C et al. Hashimoto thyroiditis. Pediatr Endocrinol 2003; suppl. 2: 205-211.

43. Kollur SM, Sayed SE, Hag IAE. Follicular thyroid lesions coexisting with Hashimoto thyroiditis: incidence and possible sources of diagnostic errors. Diagn Cytopathol 2003; 28: 35-38. 